\title{
Circumpolar dataset of sequenced specimens of Promachocrinus kerguelensis (Echinodermata, Crinoidea)
}

\author{
Lenaïg G. Hemery', Nadia Améziane', Marc Eléaume' \\ I Muséum national d'Histoire naturelle, Département des Milieux et Peuplements Aquatiques, UMR 7208- \\ MNHN, UPMC, CNRS, IRD-207, CP26, 57 rue Cuvier, 75231 Paris Cedex 05, Paris, France \\ Corresponding author: Lenaïg G. Hemery (lhemery@mnhn.fr)
}

Academic editor: V. Chavan | Received 28 May 2013 | Accepted 27 June 2013 | Published 4 July 2013

Citation: Hemery LG, Améziane N, Eléaume M (2013) Circumpolar dataset of sequenced specimens of Promachocrinus kerguelensis (Echinodermata, Crinoidea). ZooKeys 315: 55-64. doi: 10.3897/zookeys.315.5673 Resource ID: GBIF key: http://gbrds.gbif.org/browse/agent?uuid=9dae1fa0-5800-4f18-8f4e-a87f05c73eb1

Resource citation: Muséum national d'Histoire naturelle (2013-) Circumpolar dataset of sequenced specimens of Promachocrinus kerguelensis (Echinodermata, Crinoidea). 1307 data records. Contributors: Hemery LG, Améziane N, Eléaume M, Anderson O, Barnes DKA, Bohn JM, Bowden DA, Brey T, Constable A, Dahms HU, Duhamel G, Griffiths HJ, Hautecoeur M, Hibberd T, Linse K, Lockhart SJ, Lodde E, Mills S, Mooi R, Rouse GW, Sands CJ, Schiaparelli S, Schnabel K, Wilson NG. Online at http://ipt.biodiversity.aq/archive.do?r=proke, Version 5.0 (Last updated on 2013-06-17), GBIF key: http://gbrds.gbif.org/browse/agent?uuid=9dae1fa0-5800-4f18-8f4e-a87f05c73eb1. Data Paper ID: doi: 10.3897/zookeys.315.5673

\begin{abstract}
This circumpolar dataset of the comatulid (Echinodermata: Crinoidea) Promachocrinus kerguelensis (Carpenter, 1888) from the Southern Ocean, documents biodiversity associated with the specimens sequenced in Hemery et al. (2012). The aim of Hemery et al. (2012) paper was to use phylogeographic and phylogenetic tools to assess the genetic diversity, demographic history and evolutionary relationships of this very common and abundant comatulid, in the context of the glacial history of the Antarctic and Sub-Antarctic shelves (Thatje et al. 2005, 2008). Over one thousand three hundred specimens (1307) used in this study were collected during seventeen cruises from 1996 to 2010, in eight regions of the Southern Ocean: Kerguelen Plateau, Davis Sea, Dumont d'Urville Sea, Ross Sea, Amundsen Sea, West Antarctic Peninsula, East Weddell Sea and Scotia Arc including the tip of the Antarctic Peninsula and the Bransfield Strait. We give here the metadata of this dataset, which lists sampling sources (cruise ID, ship name, sampling date, sampling gear), sampling sites (station, geographic coordinates, depth) and genetic data (phylogroup, haplotype, sequence ID) for each of the 1307 specimens. The identification of the specimens was controlled by an expert taxonomist specialist of crinoids (Marc Eléaume, Muséum national d'Histoire naturelle, Paris) and all the COI sequences were matched against those available on the Barcode of Life Data System (BOLD: http://www.boldsystems.org/index.php/
\end{abstract}

Copyright Lenaïg G. Hemery et al. This is an open access article distributed under the terms of the Creative Commons Attribution License 3.0 (CC-BY), which permits unrestricted use, distribution, and reproduction in any medium, provided the original author and source are credited. 
IDS_OpenIdEngine). This dataset can be used by studies dealing with, among other interests, Antarctic and/ or crinoid diversity (species richness, distribution patterns), biogeography or habitat / ecological niche modeling. This dataset is accessible through the GBIF network at http://ipt.biodiversity.aq/resource.do?r=proke.

\section{Keywords}

Antarctica, Crinoidea, Cytochrome Oxydase subunit I, Echinodermata, Phylogeography, Promachocrinus, Southern Ocean, Sub-Antarctic

\section{Project details}

Project title: Comprehensive sampling reveals circumpolarity and sympatry in seven mitochondrial lineages of the Southern Ocean crinoid species Promachocrinus kerguelensis (Echinodermata)

Personnel: Lenaïg G. Hemery

Funding: French ANR ANTFLOCKS (n 07-BLAN-0213-01); MNHN Paris intern grants (DMPA's BQR, ATMs "Biominéralisation"; "Biodiversité actuelle et fossile; crises, stress, restaurations et panchronisme: le message systématique"; "Taxonomie moléculaire: DNA Barcode et gestion durable des collections").

Study area descriptions/descriptor: The 1307 specimens in this dataset were collected from the Southern Ocean, south of the Sub-Antarctic Front (SAF): Kerguelen Plateau (Kerguelen and Heard islands), Davis Sea, Dumont d'Urville Sea, Ross Sea, Amundsen Sea, West Antarctic Peninsula, East Weddell Sea and Scotia Arc (from the tip of the Antarctic Peninsula and the Bransfield Strait to the South Georgia island). The bathymetric range extended from 65 to 1162 meters deep.

Design description: This dataset was gathered to conduct a circumpolar phylogeographic study of the crinoid species Promachocrinus kerguelensis (Hemery et al. 2012) and designed to spatially improve the sampling of Wilson et al. (2007), which was limited to the Atlantic sector of the Southern Ocean. The aim of Hemery et al. (2012) was to test the circumpolarity of the genetic lineages of Wilson et al. (2007), and to test whether these lineages represented an under-sampling artifact of a large and genetically diverse metapopulation or whether they were truly representative of the Southern Ocean. The authors used a sampling strategy designed to cover the broadest possible genetic variation and to explore the evolutionary relationships among the seven lineages, in order to be able to conduct population analyses (Meyer and Paulay 2005). They also wanted to understand the distributional limits of each phylogroup in Promachocrinus kerguelensis to assess the connectivity displayed throughout their range, and to test the "multiple refugia" theory by studying the demographic history of each phylogroup. For this purpose, more than two thousand specimens, sampled during the most recent Antarctic cruises focused on benthic biodiversity and fixed and preserved in a way allowing for DNA extraction and amplification (fixed in ethanol or frozen), were provided by several taxonomists and benthologists from different institutions. Specimen identifications during the sampling cruises were conducted to a higher level allowed by the taxonomic skills of the collectors then checked principally at the Muséum national d'Histoire naturelle, Paris by taxonomists trained to deal with Ant- 


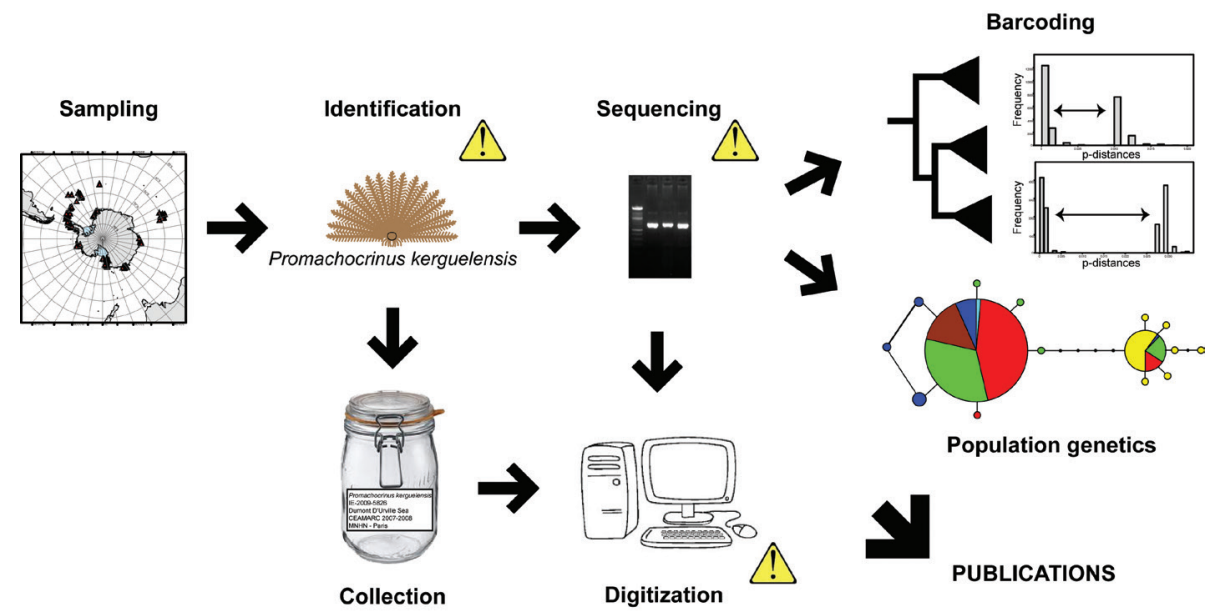

Figure I. Synoptic of the procedure used to generate the dataset. Yellow exclamatory marks show where the data quality has been checked.

arctic crinoids. The Cytochrome c Oxydase subunit I (COI) was successfully sequenced for 1307 of these specimens. Both collection data and produced sequences were digitized in appropriate databases, used or ready to be used for publishing purpose (Figure 1).

Data published through GBIF: http://ipt.biodiversity.aq/resource.do?r=proke as an Excel spreadsheet of the dataset, available through the Darwin Core Archive format at http://ipt.biodiversity.aq/archive.do?r=proke.

\section{Taxonomic coverage}

General taxonomic coverage description: This dataset focuses on the Antarctic comatulid species Promachocrinus kerguelensis (Carpenter 1888), the most abundant and morphologically variable comatulid species in the Southern Ocean (Speel and Dearborn 1983). It corresponds to the 1307 specimens sequenced in Hemery et al. (2012).

\section{Taxonomic ranks}

Phylum: Echinodermata

Class: Crinoidea

Order: Comatulida

Family: Antedonidae

Subfamily: Heliometrinae

Genus: Promachocrinus

Species: kerguelensis

Common names: echinoderm, crinoid, comatulid, feather star 


\section{Spatial coverage}

\section{General spatial coverage}

The specimens of Promachocrinus kerguelensis gathered in this dataset were collected from most of the strategic regions in the Southern Ocean (triangles in Figure 2): the Antarctic continental shelf (East Weddell Sea, Davis Sea, Dumont d'Urville Sea, Ross Sea, Amundsen Sea, West Antarctic Peninsula), the Scotia Arc islands (South Shetland, South Orkney and South Sandwich) and the Sub-Antarctic islands (South Georgia, Kerguelen and Heard). Specimens were sampled at depths ranging from $65 \mathrm{~m}$ to 1162 $\mathrm{m}$. This covers most of the known distribution area of this species (black circles in Figure 2), but only a portion of the bathymetric range for this species, which extends from $10 \mathrm{~m}$ to $2100 \mathrm{~m}$ (Speel and Deardorn 1983).

\section{Coordinates}

$76^{\circ} 49^{\prime} 58.8^{\prime \prime S}$ and $47^{\circ} 12^{\prime} 14.4^{\prime \prime S ~ L a t i t u d e ; ~} 107^{\circ} 24^{\prime} 28.8^{\prime \prime W}$ and $170^{\circ} 23^{\prime} 6^{\prime \prime} \mathrm{E}$ Longitude.

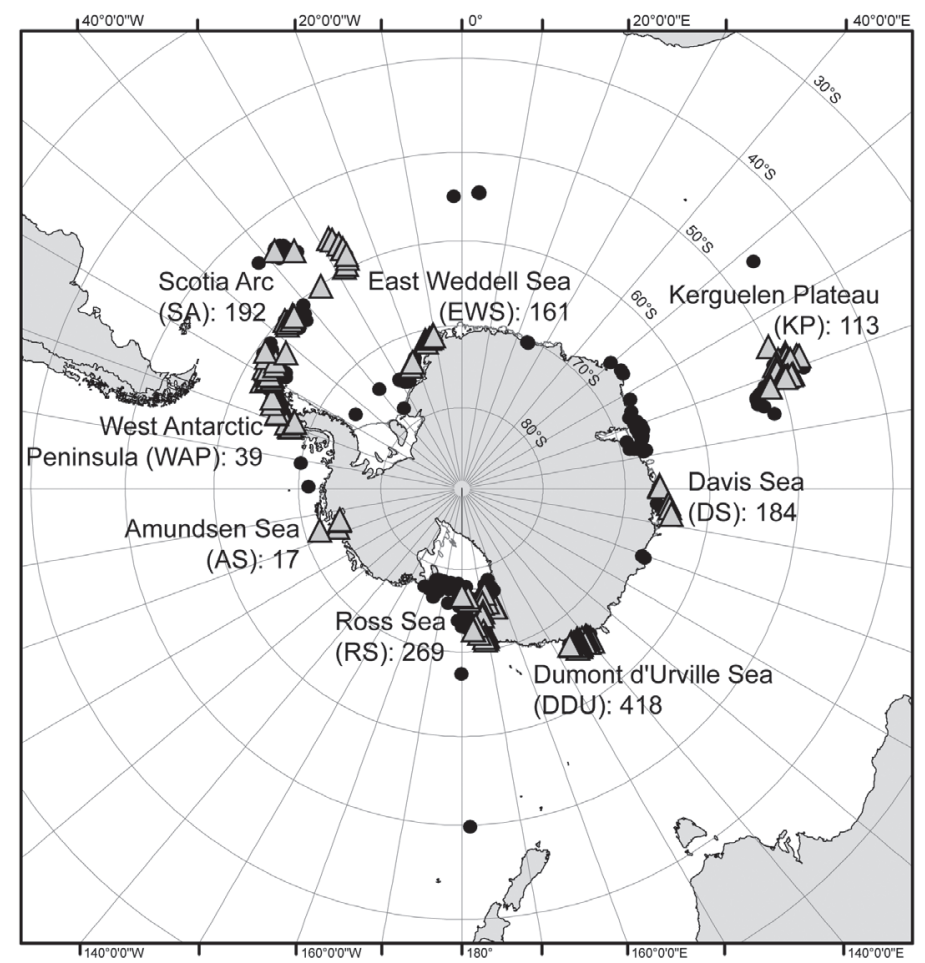

Figure 2. Promachocrinus kerguelensis sampling stations in the Southern Ocean. Triangles represent the sampled stations, circles represent the bibliographic data, numbers are sequenced specimens per region (modified from Hemery et al. 2012). 


\section{General temporal coverage}

The specimens were collected during one to four different cruises per sampling region for a total of 17 cruises from 1996 to 2010 (Figure 3). However, the number of specimens was too variable among cruises to be statistically compared (see details of numbers in the Methods part).

Temporal coverage: January 26, 1996 - March 16, 1996

Temporal coverage: March 18, 2000 - May 11, 2000

Temporal coverage: January 23, 2002 - May 5, 2002

Temporal coverage: November 17, 2003 - January 19, 2004

Temporal coverage: January 15, 2004 - March 15, 2004

Temporal coverage: February 9, 2004 - February 22, 2004

Temporal coverage: January 20, 2005 - April 7, 2005

Temporal coverage: February 27, 2006 - April 11, 2006

Temporal coverage: December 16, 2007 - January 27, 2008

Temporal coverage: February 18, 2008 - April 11, 2008

Temporal coverage: January 31, 2008 - March 16, 2008

Temporal coverage: February 6, 2009 - March 12, 2009

Temporal coverage: December 1, 2009 - December 11, 2009

Temporal coverage: December 29, 2009 - January 8, 2010

Temporal coverage: August 28, 2010 - September 28, 2010

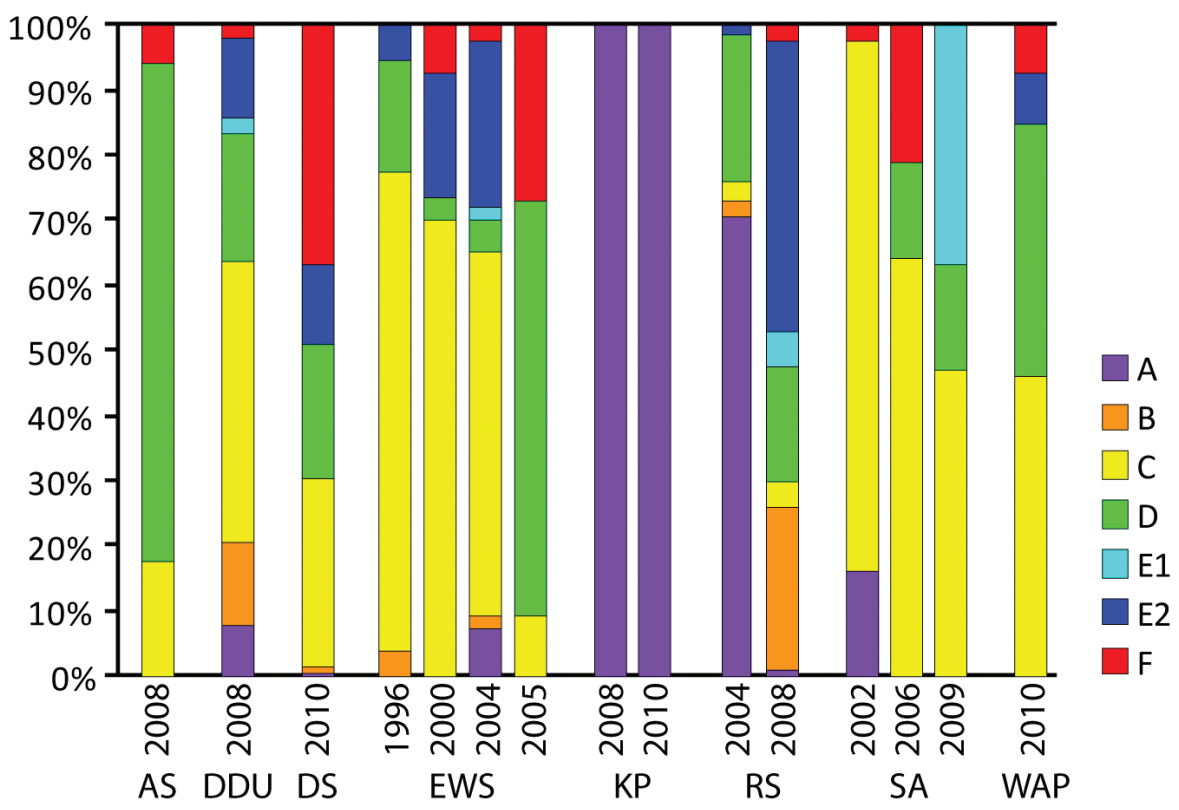

Figure 3. Proportion of specimens per phylogroup per year and sampling region. Acronyms of regions are given in Figure 2, A - F are the names of the 7 COI haplogroups found in Hemery et al. 2012. 


\section{Natural collections description}

Parent collection identifier: Muséum national d'Histoire naturelle, Paris (MNHN)

Collection name: Echinodermes (MNHN-IE)

Collection identifier: Marc Eléaume

Specimen preservation method: Alcohol

\section{Methods}

Method step description: See sampling description below and graphic summary in Figure 1.

Study extent description: The specimens were collected during 17 cruises in the Southern Ocean, from 1996 to 2010 (Figures 2 and 3): 53 specimens from EASIZ I (ANT XIII/3) onboard the RV Polarstern (1996) in the East Weddell Sea, 53 from EASIZ III (ANT XVII/3) onboard the RV Polarstern (2000) in the East Weddell Sea and the Scotia Arc, 12 from ANDEEP I\&II (ANT XIX/3\&4) and 25 from LAMPOS (ANT XIX/5) onboard the RV Polarstern (2002) in the Scotia Arc, 43 from BENDEX (ANT XXI/2) onboard the RV Polarstern (2003-2004) in the East Weddell Sea, 15 from ITALICA 2004 onboard the RV Italica (2004) in the Ross Sea, 106 from TAN0402 onboard the RV Tangaroa (2004) in the Ross Sea, 12 from ANDEEP III (ANT XXII/3) onboard the RV Polarstern (2005) in the East Weddell Sea, 14 from BIOPEARL I (JR144) onboard the RV James Clark Ross (2006) in the Scotia Arc, 418 from CEAMARC (2007/08 V3) onboard the RV Aurora Australis (2007-2008) in the Dumont d'Urville Sea, 17 from BIOPEARL II (JR179) onboard the RV James Clark Ross (2008) in the Amundsen Sea, 2 from HIMI-SC50 onboard the FV Southern Champion (2008) on the Kerguelen Plateau (Heard island), 148 from TAN0802 onboard the RV Tangaroa (2008) in the Ross Sea, 68 from AMLR 2009 Leg II onboard the RV Yuzhmorgeologiya (2009) in the Scotia Arc and the West Antarctic Peninsula, 26 from BASWAP (JR230) onboard the RV James Clark Ross (2009) in the West Antarctic Peninsula, 184 from BR09 onboard the RV Aurora Australis (2009-2010) in the Davis Sea, and 111 from POKER II onboard the FV Austral (2010) on the Kerguelen Plateau (Kerguelen island).

Sampling description: The specimens were sampled using several sampling gears, depending on the cruise: agassiz trawls, beam trawls, bottom trawls, box corers, epibenthic sledges (Arntz and Brey 2001, 2003, 2005; Arntz and Gutt 1997; Beaman and O’Brien 2009; Duhamel et al. 2011; Fahrbach 2006; Fütterer et al. 2003; Lockhart et al. 2009). During each cruise, specimens were sorted onboard and then fixed and preserved in 70-95\% ethanol or first frozen and subsequently preserved in ethanol. The specimens were curated by each institution once back from the field and digitized in their own databases before the specimens were gathered by the authors in the purpose of the molecular study. Metadata associated with each specimen were extracted from the 
cruise reports. The molecular data (barcoding) were generated following the protocols described in Ivanova et al. (2006), Eléaume et al. (2011) and Hemery et al. (2012).

Quality control description: The initial geo-referencing was done by means of the vessel onboard GPS systems. Samples identification was supervised and checked by Marc Eléaume, crinoid taxonomist at the Muséum national d'Histoire naturelle, Paris, following Clark and Clark (1967) taxonomic description of the species, and matched to the World Register of Marine Species (WoRMS). The barcoding was done by Lenaïg G. Hemery at the Muséum national d'Histoire naturelle, Paris, and by the Canadian Center for DNA Barcoding, Toronto, and the Scripps Institution of Oceanography, San Diego, and matched to sequences already available on the Barcode of Life Data System (BOLD: http://www.boldsystems.org/index.php/IDS_OpenIdEngine). All sequences, specimen occurrences and identifications are linked together through unique numbers in BOLD under the public project name PROKE.

\section{Datasets}

Dataset description: This dataset has been generated for a molecular study of the Antarctic comatulid species Promachocrinus kerguelensis, improving the geographic coverage of the previous study by Wilson et al. (2007). All the specimens are identified by several types of numbers that are linked together: Sample ID (characteristic of each individual), BOLD ID, GenBank ID and SeqID (all three characteristic of each sequence in different databases), Field Number (when available) and Museum ID. In some cases, the two last identifiers are shared by several individuals identifiable from each other by their own Sample ID. The dataset also includes the name of the institution storing the specimens, the complete taxonomy, names of identifiers and collectors, and information on the sampling itself: cruise names, vessel names, sampling gears, dates, regions, sectors, exact sites (when available), station numbers, latitudes and longitudes in decimal degrees, and depths in meters. This dataset is suitable to be used in studies dealing with, for example, Antarctic and/or crinoid diversity (species richness, distribution patterns), biogeography or habitat / ecological niche modeling.

Object name: Darwin Core Archive Circumpolar dataset of sequenced specimens of Promachocrinus kerguelensis (Echinodermata, Crinoidea)

Character encoding: UTF-8

Format name: Darwin Core Archive format

Format version: 1.0

Distribution: http://ipt.biodiversity.aq/archive.do?r=proke

Publication date of data: 2012-03-01

Language: English

Metadata language: English

Date of metadata creation: 2012-04-25

Hierarchy level: Dataset 


\section{Acknowledgements}

The authors thank Sarah Henkel and the two anonymous reviewers who helped to improve this manuscript, and all the contributors who furnished the samples: Anderson O, Barnes DKA, Bohn JM, Bowden DA, Brey T, Constable A, Dahms HU, Duhamel G, Griffiths HJ, Hautecoeur M, Hibberd T, Linse K, Lockhart SJ, Lodde E, Mills S, Mooi R, Rouse GW, Sands CJ, Schiaparelli S, Schnabel K, Wilson NG.

\section{References}

\section{Literature referred within metadata}

Arntz WE, Brey T (2001) The expedition ANTARKTIS XVII/3 (EASIZ III) of RV Polarstern in 2000. Berichte zur Polar- und Meeresforschung 402: 1-181.

Arntz WE, Brey T (2003) The expedition ANTARKTIS XIX/5 (LAMPOS) of RV Polarstern in 2002. Berichte zur Polar- und Meeresforschung 462: 1-124.

Arntz WE, Brey T (2005) The Expedition ANTARKTIS XXI/2 (BENDEX) of RV Polarstern in 2003/2004. Berichte zur Polar- und Meeresforschung 503: 1-149.

Arntz WE, Gutt J (1997) The Expedition ANTARKTIS XIII/3 (EASIZ I) of RV Polarstern to the eastern Weddell Sea in 1996. Berichte zur Polar- und Meeresforschung 249: 1-148.

Beaman RJ, O'Brien PE (2009) Collaborative East Antarctic marine census (CEAMARC): Post-survey report, RSV Aurora Australis Voyage 3, December 2007-January 2008. Geoscience Australia Record 2009/05: 1-61.

Carpenter PH (1888) Report on the Crinoidea collected during the voyage of H.M.S. Challenger, during the years 1873-76, Part II - The Comatulae. Report on the Scientific Results of the Voyage of H.M.S. Challenger, Zoology, London 26(60): 1-399.

Clark AH, Clark AM (1967) A monograph of the existing crinoids. Volume 1 - The comatulids. Part 5 - Suborders Oligophreata (concluded) and Macrophreata. Bulletin of the United States National Museum 82: 1-795.

Duhamel G, Hautecœur M, Pruvost P, Gasco N, Charassin JB, Roquet F, Eléaume M, Moreau C, Laffargue P, Hemery LG, Martin A, Chai N, Mah C, Améziane N, Prudor A, Marteau C, Bigger E, Cascade S, Aubert JL, Beaujean A, Moiroux N (2011) POKER 2 Campagne d'évaluation de la biomasse de poissons à Kerguelen. Rapport de Campagne. Muséum National d'Histoire Naturelle, Paris.

Eléaume M, Hemery LG, Bowden DA, Roux M (2011) A large new species of the genus Ptilocrinus (Echinodermata, Crinoidea, Hyocrinidae) from Antarctic seamounts. Polar Biology, 34: 1385-1397. doi: 10.1007/s00300-011-0993-2

Fahrbach E (2006) The Expedition ANTARKTIS-XXII/3 of the Research Vessel Polarstern in 2005. Berichte zur Polar- und Meeresforschung 533: 1-246.

Fütterer DK, Brandt A, Poore GCB (2003) The Expeditions ANTARKTIS-XIX/3-4 of the Research Vessel Polarstern in 2002 (ANDEEP I and II: Antarctic benthic deep-sea biodiversity - colonization history and recent community patterns). Berichte zur Polar- und Meeresforschung 470: 1-174. 
Hemery LG, M Eléaume M, Roussel V, Améziane N, Gallut C, Steinke D, Cruaud C, Couloux A, Wilson NG (2012) Comprehensive sampling reveals circumpolarity and sympatry in seven mitochondrial lineages of the Southern Ocean crinoid species Promachocrinus kerguelensis (Echinodermata), Molecular Ecology 21: 2502-2518. doi: 10.1111/j.1365294X.2012.05512.x

Ivanova NV, Dewaard JR, Hebert PD (2006) An inexpensive, automation-friendly protocol for recovering high-quality DNA. Molecular Ecology Notes 6: 998-1002. doi: 10.1111/j.1471-8286.2006.01428.x

Lockhart S, Wilson NG, Lazo-Wasem E, Jones C (2009) Benthic invertebrate composition and characterization of the South Orkney Islands. In: Van Cise (Ed) AMLR 2008/2009 Field season report: Objectives, accomplishments and tentative conclusions. Southwest Fisheries Science Center, Antarctic Ecosystem Research Group, 67-76.

Meyer CP, Paulay G (2005) DNA barcoding: error rates based on comprehensive sampling. PLoS Biology 3: e422. doi: 10.1371/journal.pbio.0030422

Thatje S, Hillebrand CD, Larter R (2005) On the origin of Antarctic marine benthic community tructure. Trends in Ecology and Evolution 20(10): 534-540. doi: 10.1016/j. tree.2005.07.010

Thatje S, Hillebrand CD, Mackensen A, Larter R (2008) Life hung by a thread: Endurance of Antarctic fauna in glacial periods. Ecology 89: 682-692. doi: 10.1890/07-0498.1

Speel JA, Dearborn JH (1983) Comatulid crinoids from the R/V Eltanin cruises in the Southern Ocean. Antarctic Research Series 38: 1-60. doi: 10.1029/AR038p0001

Wilson NG, Hunter RL, Lockhart SJ, Halanych KM (2007) Multiple lineages and absence of panmixia in the "circumpolar" crinoid Promachocrinus kerguelensis from the Atlantic sector of Antarctica. Marine Biology 152: 895-904. doi: 10.1007/s00227-007-0742-9

\section{Literature used to develop and improve the dataset}

Arntz WE, Brey T (2001) The expedition ANTARKTIS XVII/3 (EASIZ III) of RV Polarstern in 2000. Berichte zur Polar- und Meeresforschung 402: 1-181.

Arntz WE, Brey T (2003) The expedition ANTARKTIS XIX/5 (LAMPOS) of RV Polarstern in 2002. Berichte zur Polar- und Meeresforschung 462: 1-124.

Arntz WE, Brey T (2005) The Expedition ANTARKTIS XXI/2 (BENDEX) of RV Polarstern in 2003/2004. Berichte zur Polar- und Meeresforschung 503: 1-149.

Arntz WE, Gutt J (1997) The Expedition ANTARKTIS XIII/3 (EASIZ I) of RV Polarstern to the eastern Weddell Sea in 1996. Berichte zur Polar- und Meeresforschung 249:1-148.

Beaman RJ, O’Brien PE (2009) Collaborative East Antarctic marine census (CEAMARC): Post-survey report, RSV Aurora Australis Voyage 3, December 2007-January 2008. Geoscience Australia Record 2009/05: 1-61.

Duhamel G, Hautecour M, Pruvost P, Gasco N, Charassin JB, Roquet F, Eléaume M, Moreau C, Laffargue P, Hemery LG, Martin A, Chai N, Mah C, Améziane N, Prudor A, Marteau C, Bigger E, Cascade S, Aubert JL, Beaujean A, Moiroux N (2011) POKER 2 - Campagne d'évaluation de la biomasse de poissons à Kerguelen. Rapport de Campagne. Muséum National d'Histoire Naturelle, Paris. 
Fahrbach E (2006) The Expedition ANTARKTIS-XXII/3 of the Research Vessel Polarstern in 2005. Berichte zur Polar- und Meeresforschung 533: 1-246.

Fütterer DK, Brandt A, Poore GCB (2003) The Expeditions ANTARKTIS-XIX/3-4 of the Research Vessel Polarstern in 2002 (ANDEEP I and II: Antarctic benthic deep-sea biodiversity - colonization history and recent community patterns). Berichte zur Polar- und Meeresforschung 470: 1-174.

Lockhart S, Wilson NG, Lazo-Wasem E, Jones C (2009) Benthic invertebrate composition and characterization of the South Orkney Islands. In: Van Cise (Ed) AMLR 2008/2009 Field season report: Objectives, accomplishments and tentative conclusions. Southwest Fisheries Science Center, Antarctic Ecosystem Research Group, 67-76.

\section{Literature that has used data from this dataset}

Hemery LG, M. Eléaume M, Roussel V, Améziane N, Gallut C, Steinke D, Cruaud C, Couloux A, Wilson NG (2012) Comprehensive sampling reveals circumpolarity and sympatry in seven mitochondrial lineages of the Southern Ocean crinoid species Promachocrinus kerguelensis (Echinodermata), Molecular Ecology 21: 2502-2518. doi: 10.1111/j.1365294X.2012.05512.x

\section{Appendix}

Sampling data associated to the 1307 specimens of Promachocrinus kerguelensis sequenced in Hemery et al. (2012). (doi: 10.3897/zookeys.315.5673.app) File format: Comma Separated Value (csv).

Explanation note: Each sample is associated to three unique sequence IDs (BOLD ID, GenBank ID and SeqID); Haplotype and Clade refer back to the genetic data from Hemery et al. (2012); Latitude and Longitude are given in decimal degrees; Depth is given in meters.

Copyright notice: This dataset is made available under the Open Database License (http://opendatacommons.org/licenses/odbl/1.0/). The Open Database License $(\mathrm{ODbL})$ is a license agreement intended to allow users to freely share, modify, and use this Dataset while maintaining this same freedom for others, provided that the original source and author(s) are credited.

Citation: Hemery LG, Améziane N, Eléaume M (2013) Circumpolar dataset of sequenced specimens of Promachocrinus kerguelensis (Echinodermata, Crinoidea). ZooKeys 315: 55-64. doi: 10.3897/zookeys.315.5673 Sampling data associated to the 1307 specimens of Promachocrinus kerguelensis sequenced in Hemery et al. (2012). doi: 10.3897/ zookeys.315.5673.app 